\title{
Assessing Functional Capacity and Factors Determining Functional Decline in the Elderly: A Cross-Sectional Study
}

\author{
Avaliação da Capacidade Funcional e Fatores \\ Determinantes do Declínio Funcional em Idosos: \\ Um Estudo Transversal
}

\author{
Anamélia OLIVEIRA $\triangle^{1}$, Paulo NOSSA ${ }^{2}$, Anabela MOTA-PINTO1 \\ Acta Med Port 2019 Oct;32(10):654-660 - https://doi.org/10.20344/amp.11974
}

\section{ABSTRACT}

Introduction: The aim of this study is to assess functional capacity and determine the factors associated with functional decline in the elderly in adult day care centres and home care support in the County of Coimbra, Portugal.

Material and Methods: Cross-sectional study. A total of 115 participants of both genders, aged between 65 and 98 , were enrolled in the home care support and adult day care system of the County of Coimbra, Portugal. Functional capacity was assessed using the Barthel index and the Lawton index. Another questionnaire gathered social, demographic and health status information.

Results: The basic activities of daily living were significantly associated with age, cohabitation, medication usage, falls and multiple morbidity. Analysis of the study's variables and the instrumental activities of daily living found significant associations between age, institutional affiliation, perceived health status, hospitalizations, medication usage, physical exercise, multiple morbidities, falls, and fall prevention.

Discussion: The results demonstrate that no statistically observable differences were found between gender and functional dependence. A significant association between the Barthel index and cohabitation was also found. We should also highlight that this sample revealed the extremely important role of families in determining the protection of highly dependent older people. Likewise, a significant association was observed between instrumental activities of daily living and levels of physical activity in which greater independence was found in those seniors who practiced physical exercise three or more times per week.

Conclusion: The results of this study allow us to identify factors that may be associated with the functional decline in the elderly. Useful evidence for the adoption of intervention strategies in the elderly population was added, focused on the prevention of functional decline and maintenance of the functional capacities of the elderly.

Keywords: Accidental Falls; Activities of Daily Living; Aging; Portugal; Public Health; Risk Factors

\section{RESUMO}

Introdução: Foi objectivo este estudo avaliar a capacidade funcional e determinar os fatores associados ao declínio funcional dos idosos num centro de dia e apoio domiciliário no Concelho de Coimbra, Portugal.

Material e Métodos: Estudo transversal. Participaram no estudo 115 indivíduos de ambos os géneros, com idades entre os 65 - 98 anos, que utilizaram os serviços de apoio domiciliário e centro de dia no Concelho de Coimbra, Portugal. A capacidade funcional foi avaliada através dos questionários: índice de Barthel e índice de Lawton. Foi utilizado um questionário para caracterização sociodemográfica e do estado de saúde dos participantes.

Resultados: $\mathrm{Na}$ análise, as atividades básicas da vida diária tiveram associação significativa com idade, coabitação, uso de medicamentos, quedas e presença de multimorbilidade. Na análise entre as variáveis de estudo e as atividades instrumentais da vida diária, houve associação significativa com idade, vínculo com instituição, perceção do estado de saúde, internamento hospitalar, uso de medicamento, prática de atividades física, presença de multimorbilidade, quedas e prevenção de quedas.

Discussão: Os resultados demonstram que não foram encontradas diferenças estatisticamente observáveis entre género e dependência funcional. Quando a relação entre as habilidades funcionais e a coabitação foi analisada, houve uma relação significativa entre o índice de Barthel e a coabitação. Sublinha-se que essa amostra revelou o papel altamente importante das famílias na determinação da proteção de pessoas idosas muito dependentes, bem como foi observada uma relação significativa entre as atividades instrumentais da vida diária e os níveis de atividade física, em que maior independência foi encontrada nos idosos que praticavam exercício físico três ou mais vezes por semana.

Conclusão: Os resultados deste estudo permitem identificar fatores que podem estar associados ao declínio funcional dos idosos. Acrescentam evidências úteis para a adoção de estratégias de intervenção nesta população, focadas na prevenção do declínio funcional e na manutenção das capacidades funcionais dos idosos.

Palavras-chave: Atividades da Vida Diária; Envelhecimento; Fatores de Risco; Portugal; Quedas Acidentais; Saúde pública

\section{INTRODUCTION}

In Portugal $21.5 \%$ of residents are older than 65 years of age (2017), and it is predicted that the number will rise to $26.8 \%$ by 2030 . There are currently 148.7 elderly for each 100 young individuals, and $48.8 \%$ of those seniors are above 75 years old. ${ }^{1}$ This is the reason why it is important that health conditions of this population as well as their functional capacity be evaluated and institutions caring for

1. Faculty of Medicine. University of Coimbra. Coimbra. Portugal.

2. Faculty of Arts and Humanities. University of Coimbra/CEGOT. Coimbra. Portugal.

$\triangle$ Autor correspondente: Anamélia Oliveira. anameliaalmeida@hotmail.com

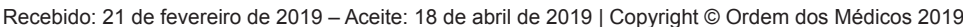


these older people must establish guidelines concerning prevention strategies.

Functional capacity is characterized by people's ability to carry out daily activities independently and autonomously, while staying in contact with their home environment. The loss of functioning in seniors is associated with multiple factors and with heightened risks of institutionalization and falls. ${ }^{2}$

Functional decline makes the elderly more vulnerable and dependent, leading to a decrease in their well-being and quality of life. ${ }^{3}$ This justifies the need to assess the functionality of this population. Such an assessment will enable professionals to detect potential risks of functional decline and measure levels of dependency. It will also facilitate the design of preventive strategies and even combat the onset of physical frailty that takes place at advanced ages and contribute to the promotion of early interventions. ${ }^{4}$

The literature has identified factors associated with functional decline. However, few studies ${ }^{5,6}$ have dealt with the link between functional decline and a range of multidimensional factors. Researchers generally focus on just one specific condition in order to determine the functional incapacity of older people, and this hinders the detailed identification of a wider range of determining factors. It has been noted that research dealing with the functional capacity of the elderly and the determining factors is highly pertinent, as they might facilitate the implementation of interventions and preventive measures. ${ }^{5}$ This study aims to assess functional capacity and determine the factors associated with functional decline in the elderly in adult day care centres and home care support of the County of Coimbra, Portugal.

\section{MATERIAL AND METHODS}

This was a cross-sectional study. The sample included 115 participants of both genders with ages ranging from 65 to 98 years old. The inclusion criteria were: age equal to or above 65, both genders, users of home care services (HCS) or adult day care services (ADHS) and being a resident in the County of Coimbra. Participants gave their voluntary agreement by signing an informed consent form. The exclusion criteria included participants with cognitive changes based on the previous diagnostic criteria elaborated and measured by the attending physician. Participants from a convenience sample were recruited in two separate timepoints and settings: at the adult day care services and the home care services between May and June 2016. The first phase took place at the adult day care centre and 85 older people took part. The second phase occurred at the home care services, where 30 seniors participated.

A five-part questionnaire was used. The first section included social and demographic information (gender, age, marital status, neighbourhoods, care received, cohabitation, income). The second and third parts evaluated participants' clinical histories. The fourth and fifth sections dealt with lifestyles and participants' self-assessment of their state of health and emotional well-being. The instrument was adapted from the questionnaire that was previously used in the Study of the Aging Profile of the Portuguese Population ${ }^{7}$ and the information was collected by the researchers, after reading and explaining questions or statements, because some elderly people, of both groups, had a low level of education and/or evidence of writing difficulties.

The Barthel index and the Lawton index evaluated participants' basic activities of daily living (BADL) and instrumental activities of daily living (IADL)..$^{8,9}$

Following the data collection and the assessment of participants' BADL and IADL, the information was subject to statistical analysis using a version of the IBM/SPSS (Statistical Package for the Social Sciences) and descriptive and inferential analyses were carried out; the chi-square test was used as an independence test.

The Cronbach alpha ${ }^{10}$ was above 0.80 for each scale, and it was judged that the data appropriately assessed just one factor for each scale, which represented high levels of internal consistency.

The participants were guaranteed the right to anonymity and confidentiality. Each one signed an informed consent form. They were also informed about the goals and the reasons behind the procedures used, and they were provided with the telephone number of the lead researcher. The project was approved by the Ethics Committee of the Faculty of Medicine of the University of Coimbra (reference CE-032/2016).

\section{RESULTS}

The 115 participants ranged in age between 65 to 98 years old with a modal class between 75 to 84 years old (46.1\%). The median age was 80.4 years. Women predominated $(n=90 ; 78.3 \%)$, a fact that reflected the longer life expectancy of females, which is also true within the Portuguese general population (men 81.3 years; women 84.3 years). Most participants were widowed ( $n=75$; $65.2 \%$ ) and lived in the city of Coimbra or on the rural periphery $(n=100 ; 86.9 \% ; n=15 ; 13.1 \%)$. In this study, $73.9 \%$ $(n=85)$ were enrolled in adult day care centres and $26.1 \%$ $(n=30)$ were supported by home care services. Most of them were retired or were pensioners $(n=106 ; 92.2 \%)$, and 48.7\% lived alone (Table 1).

The descriptive analysis of lifestyle and healthcare (Table 2) revealed that $86.1 \%(n=99)$ reported eating a healthy diet while $13.9 \%(n=16)$ described a less healthy one. In terms of sleep quality, $56.5 \%(n=65)$ used sleeping medication and, $33.9 \%(n=39)$ reported having difficulty sleeping. There was considerable variability in the amount of physical activity: guided exercise, walking or gardening, at least 20 minutes, performed at least three times a week. Only $9.6 \%(n=11)$ reported getting physical activity three or more times per week. This activity is organized by the aforementioned institutions and provided by specialized professionals who carry out programmes designed for seniors. Although some participants showed walking difficulties with mobility changes ( $n=22 ; 19.1 \%$ ), none of them were permanently bedridden.

As far as falls are concerned, $73 \%(n=84)$ participants reported having fallen, $36.5 \%(n=42)$ of which within the 
Table 1 - Social and demographic characteristics of the sample

\begin{tabular}{|c|c|c|}
\hline Variable & $\mathbf{N}^{\circ}$ & $\%$ \\
\hline \multicolumn{3}{|l|}{ Gender } \\
\hline Male & 25 & 21.7 \\
\hline Female & 90 & 78.3 \\
\hline \multicolumn{3}{|l|}{ Age } \\
\hline $65-74$ & 27 & 23.5 \\
\hline $75-84$ & 53 & 46.1 \\
\hline $85+$ & 35 & 30.4 \\
\hline \multicolumn{3}{|l|}{ Marital Status } \\
\hline Married & 19 & 16.5 \\
\hline Widowed & 75 & 65.2 \\
\hline Single & 12 & 10.4 \\
\hline Separated/Divorced & 9 & 7.8 \\
\hline \multicolumn{3}{|l|}{ Neighbourhoods } \\
\hline City & 100 & 87.0 \\
\hline Rural & 15 & 13.0 \\
\hline \multicolumn{3}{|l|}{ Care received } \\
\hline Adult day care & 85 & 73.9 \\
\hline Home care & 30 & 26.1 \\
\hline \multicolumn{3}{|l|}{ Cohabitation } \\
\hline Alone & 56 & 48.7 \\
\hline Spouse & 16 & 13.9 \\
\hline Children & 31 & 27.0 \\
\hline Other family & 10 & 8.7 \\
\hline Others & 2 & 1.8 \\
\hline \multicolumn{3}{|l|}{ Income } \\
\hline Pension & 106 & 92.2 \\
\hline Actively working & 3 & 2.6 \\
\hline Dependent on family income & 3 & 2.6 \\
\hline Other & 3 & 2.6 \\
\hline
\end{tabular}

last year and $21.8 \%(n=25)$ reported sequelae resulting from falls, although without changes in gait or mobility, while $32.2 \%(n=37)$ reported no sequelae.

Regarding access to medical care, $52.2 \%(n=60)$ of the participants reported having had $3-4$ medical consultations in the previous year and $74.8 \%(n=86)$ reported having been hospitalized and $50.4 \%(n=58)$ of the participants reported being polymedicated, taking five or more medicines per day. When multiple morbidities were assessed, $81.7 \%(n=94)$ of the individuals presented at least two conditions. The pattern of morbidity was characterized by the predominance of cerebral and cardiovascular illness (69\%) followed by $67 \%$ with emotional/psychological disturbances, while $64 \%$ suffered from rheumatologic disorders. Based on their reports about chronic illness, participants reported an average of 3.68 conditions per person with the modal class being five $(22 \%)$.

As far as self-perception of the state of physical and emotional health and quality of life was concerned (Table 3 ), $71.3 \%(n=82)$ stated that their conditions interfered with their quality of life ${ }^{7}$.

Regarding the results of functional capacity in the BADL and IADL, just $40 \%(n=46)$ of the seniors were 'independent' for BADL, while for IADL 38.3\% ( $n=44)$ was measured as 'severely dependent'.

Table 4 presents the relationship between the basic and instrumental activities of daily life. The levels found for age, place of residence, cohabitation, affiliation with a health
Table 2 - Sample lifestyle and healthcare

\begin{tabular}{|c|c|c|}
\hline Variable & $\mathrm{N}^{\circ}$ & $\%$ \\
\hline $\begin{array}{l}\text { Diet (self-report) } \\
\text { Not healthy } \\
\text { Healthy }\end{array}$ & $\begin{array}{l}16 \\
99\end{array}$ & $\begin{array}{l}13.9 \\
86.1\end{array}$ \\
\hline $\begin{array}{l}\text { Sleep quality } \\
\text { Bad } \\
\text { Good }\end{array}$ & $\begin{array}{l}39 \\
76\end{array}$ & $\begin{array}{l}33.9 \\
66.1\end{array}$ \\
\hline $\begin{array}{l}\text { Physical activity (weekly) } \\
\text { None } \\
1 \text { or } 2 \text { times } \\
3 \text { or } 4 \text { times } \\
5 \text { or } 6 \text { times } \\
\text { Daily }\end{array}$ & $\begin{array}{r}53 \\
51 \\
5 \\
3 \\
3\end{array}$ & $\begin{array}{r}46.1 \\
44.3 \\
4.3 \\
2.6 \\
2.6\end{array}$ \\
\hline $\begin{array}{l}\text { Hospitalizations } \\
\text { No } \\
\text { Yes }\end{array}$ & $\begin{array}{l}29 \\
86\end{array}$ & $\begin{array}{l}25.2 \\
74.8\end{array}$ \\
\hline $\begin{array}{l}\text { Falls } \\
\qquad \text { No falls } \\
\text { Yes }(>1 \text { year }) \\
\text { Yes (<1 year) }\end{array}$ & $\begin{array}{l}31 \\
42 \\
42\end{array}$ & $\begin{array}{l}27.0 \\
36.5 \\
36.5\end{array}$ \\
\hline $\begin{array}{l}\text { Sequelae (falls) } \\
\text { Without sequelae } \\
\text { Sequelae without changes in gait and/or } \\
\text { mobility } \\
\text { Sequelae with gait and/or mobility changes } \\
\text { No falls }\end{array}$ & $\begin{array}{l}37 \\
25 \\
22 \\
31\end{array}$ & $\begin{array}{l}32.2 \\
21.8 \\
19.1 \\
26.9\end{array}$ \\
\hline $\begin{array}{l}\text { Number of medical consultations } \\
\text { (last year) } \\
\text { None } \\
1 \text { or } 2 \text { consultations } \\
3 \text { or } 4 \text { consultations } \\
5 \text { or more consultations }\end{array}$ & $\begin{array}{r}5 \\
25 \\
60 \\
25\end{array}$ & $\begin{array}{r}4.3 \\
21.7 \\
52.2 \\
21.7\end{array}$ \\
\hline $\begin{array}{l}\text { Daily medication } \\
\text { None } \\
\begin{array}{l}1 \text { or } 2 \\
3 \text { or } 4 \\
5 \text { or more }\end{array}\end{array}$ & $\begin{array}{l}11 \\
11 \\
35 \\
58\end{array}$ & $\begin{array}{r}9.6 \\
9.6 \\
30.4 \\
50.4\end{array}$ \\
\hline $\begin{array}{l}\text { Sleeping medication } \\
\text { No } \\
\text { Yes }\end{array}$ & $\begin{array}{l}50 \\
65\end{array}$ & $\begin{array}{l}43.5 \\
56.5\end{array}$ \\
\hline $\begin{array}{l}\text { Presence of multiple morbidities } \\
\text { Yes } \\
\text { No }\end{array}$ & $\begin{array}{l}94 \\
21\end{array}$ & $\begin{array}{l}81.7 \\
18.3\end{array}$ \\
\hline $\begin{array}{l}\text { Prevalent chronic disease } \\
\text { Cardiovascular disease } \\
\text { Emotional/psychological disorders } \\
\text { Rheumatologic disease } \\
\text { Vision impairment } \\
\text { Hearing loss } \\
\text { Diabetes }\end{array}$ & $\begin{array}{l}79 \\
77 \\
74 \\
69 \\
43 \\
26\end{array}$ & $\begin{array}{l}68.7 \\
67.0 \\
64.3 \\
60.0 \\
37.4 \\
22.6\end{array}$ \\
\hline
\end{tabular}

care institution, state of health, hospitalizations, medication, physical activity, comorbidity, falls, and fall prevention were all positively associated with BADL and/or IADL, while gender, social response, emotional state, medical consultations, and diet did not show any kind of association.

\section{DISCUSSION}

When analysed by age, there were significant differences in functional dependence between the cohorts $(65-74$; $75-84 ; \geq 85$ years), according to which dependence for the execution of basic $\left(X^{2}=12.694 ; p=0.048\right)$ and instrumental 
Table 3 - Health self-evaluation, emotional status and impact of illness on quality of life

\begin{tabular}{lrr}
\hline Variable & $\mathbf{N}^{\mathbf{0}}$ & $\%$ \\
\hline Health self-evaluation & & \\
$\quad$ Very good & 6 & 5.2 \\
Good & 18 & 15.7 \\
$\quad$ Fair & 81 & 70.4 \\
$\quad 10$ & 8.7 \\
Poor & & \\
Emotional status & 5 & 4.3 \\
$\quad$ Very good & 35 & 30.4 \\
$\quad$ Good & 63 & 54.8 \\
$\quad$ Fair & 12 & 10.4 \\
$\quad$ Poor & & \\
IIIness interfered with their quality of life & 82 & 71.3 \\
$\quad$ Yes & 33 & 28.7 \\
$\quad$ No &
\end{tabular}

activities $\left(x^{2}=17.508 ; p=0.002\right)$ tended to increase with age (Table 5 and 6).

These results concur with other studies which found a similar functional decline in older groups., ${ }^{5,11}$ Other studies $^{12,14}$ have also found that, with aging, the likelihood of dependence for IADL rise as does that for BADL, since the ability to carry out tasks involves the integration of multiple physiological systems which become gradually compromised with increasing age. With aging, seniors witness physical limitations with repercussions for their physical, intellectual and social functioning. This is due to the nature of aging itself, in which the amount and quality of information needed for efficient cognitive and motor control is reduced. Organic systems also undergo functional decline. Although many of these changes do not significantly decrease the performance of the daily needs of the majority of the population, they may lead to an increased risk of some individuals developing some sort of functional restriction. ${ }^{13}$
The current sample was comprised of mostly females (78\%). No statistically observable differences were found between gender and functional dependence $\left(x^{2}=3.058\right.$; $\left.p=0.383 ; X^{2}=5.513 ; p=0.064\right)$, although there was greater dependence found in BADL among women.

When the relationship between functional abilities and cohabitation were examined, there was a significant association between the Barthel index and cohabitation $\left(x^{2}=30.894\right.$; $p=0.009$ ), with greater levels of dependency among those participants who lived with family members and greater independence among those who lived with a spouse.

Formal and informal networks of social support providing care to the elderly and incapacitated patients help to maintain these populations in the community and they represent an important factor for social inclusion and autonomy. ${ }^{15,17}$ Our sample revealed the highly important role of families in determining the protection of highly dependent older people and it made a significant contribution to their ability to stay in their own homes. However, the type of support and the form of support varied according to social class. ${ }^{18}$ Families with lower incomes mostly search out lower cost social support, namely, home care, as a result of the limited pensions that a significant number of the Portuguese elderly receive with $15.1 \%$ of Portuguese retirees living at risk of poverty. ${ }^{1}$ Recent decades have seen changes in Portuguese family structures with a marked increase in the number of single person households (1960: 11.5\%; 2011: 20.4\%). Moreover, many seniors live on their own in their homes (1981: $2.0 \%$; 2011: $4.15 \%$ ). Despite these two facts, the network of family assistance continues to be the main source of support for dependent elderly people. ${ }^{19}$

In terms of physical exercise, a significant association was observed between IADL and levels of physical activity

Table 4 - Association between BADL, IADL and the study variables

\begin{tabular}{|c|c|c|c|c|}
\hline \multirow[b]{2}{*}{ Variables } & \multicolumn{2}{|c|}{ BADL } & \multicolumn{2}{|c|}{ IADL } \\
\hline & Chi-square $\left(x^{2}\right)$ & $p$ & Chi-square $\left(x^{2}\right)$ & $p$ \\
\hline Age & 12.694 & $0.048^{\star *}$ & 17.508 & $0.002^{* *}$ \\
\hline Gender & 3.058 & 0.383 & 5.513 & 0.064 \\
\hline Residence & 33.323 & $0.001^{*}$ & 7.038 & 0.317 \\
\hline Cohabitation & 30.894 & $0.009^{* *}$ & 4.983 & 0.056 \\
\hline Support from charity institutions & 4.983 & 0.173 & 4.391 & 0.111 \\
\hline Institutional affiliation & 0.752 & 0.386 & 4.293 & $0.038^{* *}$ \\
\hline State of health & 15.395 & 0.081 & 43.315 & $0.001^{*}$ \\
\hline Emotional status & 10.700 & 0.297 & 9.126 & 0.167 \\
\hline Hospitalizations & 2.238 & 0.525 & 10.433 & $0.005^{* *}$ \\
\hline Number of consultations & 9.163 & 0.422 & 6.242 & 0.397 \\
\hline Medications & 17.805 & $0.038^{* *}$ & 28.268 & $0.001^{*}$ \\
\hline Diet & 2.513 & 0.473 & 0.187 & 0.911 \\
\hline Lack of physical exercise & 1.532 & 0.957 & 9.170 & $0.035^{\star *}$ \\
\hline Multiple morbidity & 11.138 & $0.011^{* *}$ & 11.207 & $0.004^{* *}$ \\
\hline Falls & 13.071 & $0.042^{* *}$ & 9.661 & $0.047^{* *}$ \\
\hline Fall related impairments & 16.499 & 0.057 & 14.261 & $0.027^{* *}$ \\
\hline
\end{tabular}

${ }^{*} p<0.01{ }^{* *} p<0.05$ 
Table 5 - Association between basic activities of daily living (BADL), age and gender

\begin{tabular}{|c|c|c|c|c|c|c|}
\hline \multirow[b]{2}{*}{ Variables } & \multicolumn{6}{|c|}{ BADL } \\
\hline & & Independent & $\begin{array}{c}\text { Very slightly } \\
\text { dependent }\end{array}$ & $\begin{array}{r}\text { Moderately } \\
\text { dependent }\end{array}$ & $\begin{array}{c}\text { Severely } \\
\text { dependent and } \\
\text { Totally dependent }\end{array}$ & $p^{*}$ \\
\hline Age & & & & & & 0.048 \\
\hline $65-74$ & \% age & $\begin{array}{c}14 \\
51.9\end{array}$ & $\begin{array}{c}1 \\
3.7\end{array}$ & $\begin{array}{c}10 \\
37.0\end{array}$ & $\begin{array}{c}2 \\
7.4\end{array}$ & \\
\hline $75-84$ & $\begin{array}{r}\mathrm{N} \\
\% \text { age }\end{array}$ & $\begin{array}{c}25 \\
47.2\end{array}$ & $\begin{array}{c}10 \\
18.9\end{array}$ & $\begin{array}{c}15 \\
28.3\end{array}$ & $\begin{array}{c}3 \\
5.7\end{array}$ & \\
\hline $85+$ & \% age & $\begin{array}{c}7 \\
20.0\end{array}$ & $\begin{array}{c}11 \\
31.4\end{array}$ & $\begin{array}{c}15 \\
42.9\end{array}$ & $\begin{array}{c}2 \\
5.7\end{array}$ & \\
\hline Gender & & & & & & 0.383 \\
\hline Male & $\%$ gender & $\begin{array}{c}12 \\
48.0\end{array}$ & $\begin{array}{c}2 \\
8.0\end{array}$ & $\begin{array}{c}10 \\
40.0\end{array}$ & $\begin{array}{c}1 \\
4.0\end{array}$ & \\
\hline Female & $\begin{array}{r}\mathrm{N} \\
\% \text { gender }\end{array}$ & $\begin{array}{c}34 \\
37.8\end{array}$ & $\begin{array}{c}20 \\
22.2\end{array}$ & $\begin{array}{c}30 \\
33.3\end{array}$ & $\begin{array}{c}6 \\
6.7\end{array}$ & \\
\hline
\end{tabular}

${ }^{*} p<0.01{ }^{* *} p<0.05$

$\left(X^{2}=9.170 ; p=0.035\right)$, in which greater independence was found in those seniors who practiced physical exercise three or more times per week. Severe dependency was greater among those who led a sedentary lifestyle. This evidence should be considered by caretaking institutions, especially regarding the planning of preventive activities for the elderly in order to try to counteract participants' lack of physical activity.

According to the literature, functional incapacity exerts a significant influence in the quality of life of older people, and it may be associated with inactivity. ${ }^{5,20}$ This lack of physical activity is highly prevalent among seniors and it influences the acceleration of the aging process and the appearance of chronic disease. It is also associated with a state of dependence, limited mobility, generalized frailty and diminished resistence. ${ }^{21}$ The decrease in muscular strength inherent to aging leads to sarcopenia, a gradual loss of strength and musculoskeletal mass that happens with age and which has a significant impact on the health of the elderly. It has functional consequences on walking and balance and increases the risk of falling, chronic disease, and functional incapacity, thereby reducing autonomy. ${ }^{22,23}$
When self-perception regarding one's state of health was analysed, despite the trend that appears in the sample, a significant association was found between the Lawton index and the state of health $\left(X^{2}=43.315 ; p=0.001\right)$. Those participants who described themselves as having a 'very good' state of health, were more independent. Selfperception of health has been recognized as an important indicator because it measures people's subjective perceptions of their physical and mental state. Since it is independent of the interpretation of symptoms, it serves as an important predictor of mortality, as well as of the use of health services. People with a poor impression of their state of health are at a greater risk of death than those who report good or excellent health. ${ }^{24,26}$

When hospitalizations were examined, a significant association was found between the Lawton Index and those people who had been hospitalized, who showed higher levels of dependency $\left(x^{2}=10.433 ; p=0.005\right)$. Hospitalization is thought to be a high-risk factor, especially for older people. Approximately half of hospitalizations of older people are most frequently caused by respiratory and circulatory diseases, as was the case in this study. In general,

Table 6 - Association between activities of daily living (IADL), age and gender

\begin{tabular}{|c|c|c|c|c|c|}
\hline \multirow[b]{2}{*}{ Variables } & \multicolumn{5}{|c|}{ IADL } \\
\hline & & Independent & Moderately dependent & Severely dependent & $p^{*}$ \\
\hline Age & & & & & 0.002 \\
\hline $65-74$ & \% age & $\begin{array}{c}6 \\
22.2\end{array}$ & $\begin{array}{l}10 \\
37\end{array}$ & $\begin{array}{c}11 \\
40.7\end{array}$ & \\
\hline $75-84$ & $\begin{array}{r}N \\
\% \text { age }\end{array}$ & $\begin{array}{c}5 \\
9.4\end{array}$ & $\begin{array}{l}35 \\
66\end{array}$ & $\begin{array}{c}13 \\
24.5\end{array}$ & \\
\hline $85+$ & $\begin{array}{r}N \\
\% \text { age }\end{array}$ & $\begin{array}{l}0 \\
0\end{array}$ & $\begin{array}{c}15 \\
42.9\end{array}$ & $\begin{array}{c}20 \\
57.1\end{array}$ & \\
\hline Gender & & & & & 0.064 \\
\hline Male & \% gender & $\begin{array}{c}5 \\
20.0\end{array}$ & $\begin{array}{c}9 \\
36.0\end{array}$ & $\begin{array}{c}11 \\
44.0\end{array}$ & \\
\hline Female & \% gender & $\begin{array}{c}6 \\
6.7\end{array}$ & $\begin{array}{c}51 \\
56.7\end{array}$ & $\begin{array}{c}33 \\
36.7\end{array}$ & \\
\hline
\end{tabular}

${ }^{*} p<0.01{ }^{* *} p<0.05$ 
hospitalization is followed by a decrease in patients' functional capacity and changes in their quality of life, which are often irreversible. Functional impairment in the early days of hospitalization may be associated with advanced age, the severity of multiple morbidities and cognitive status, which may be worsened by hospital practices (such as bed confinement, psychotropic medication, and the use of urinary catheters). ${ }^{27}$ The functional decline associated with hospitalization may impair the performance of BADL and IADL. The rate of such impairment is thought to be higher than $50 \%$ in people over 85 years of age. This change is associated with important short and longer-term results including institutionalization, disability and mortality. ${ }^{28,29}$

The analysis of daily medication found a significant association between BADL and IADL $\left(X^{2}=17.805\right.$; $p=0.038 ; X^{2}=28.268 ; p=0.001$ ), with higher levels of dependency among those seniors who took three or more medications per day. The incapacity to perform BADL was found to be an aggravating factor for polymedication, which is in line with other studies which have found an association between the lack of functional capacity and polymedication. ${ }^{30}$ For example, one study in women over 65 looked at the following: mobility, capacity for self-care, the use of the upper limbs and the ability to perform those activities that are required in order to live independently in the community. It concluded that frailty was associated with increased use of medications. ${ }^{31}$

The study of chronic disease revealed significant associations between multiple morbidities and BADL and IADL $\left(X^{2}=11.138 ; p=0.011 ; X^{2}=11.207 ; p=0.004\right)$, with higher rates of multiple morbidities in more dependent older people.

It is well-known that the most common causes of death in geriatric patients are: cardiovascular disease, cancer, stroke, and lung disease. The most common causes of morbidity are arthritis, hearing and vision loss, diabetes mellitus, Alzheimer, osteoporosis, incontinence, cognitive impairment and falls. ${ }^{32}$ These data are in line with our study, where the main causes of morbidity were: cardiovascular disease, emotional and psychological disorders, rheumatic disease, and vision impairment. Cardiac disease also had a negative influence on people's functional capacity, often being the leading determining factor of functional incapacity. ${ }^{3}$ Other researchers have found that diabetes mellitus, heart disease, and cancer have a moderate effect, while hypertension has a minor impact on functional capacity. ${ }^{33}$ The findings of the Framingham Study Cohort corroborated this idea. It found that arthritis and heart disease presented greater functional incapacities compared to other chronic diseases. ${ }^{33}$

One study looked at the data gathered as part of the Projeto Saúde, Bem-estar e Envelhecimento na América Latina e Caribe (Projeto SABE) ${ }^{34}$ that analysed 2143 people aged 60 or older, and found that chronic disease had a strong influence on these people's functional capacities. Hypertension increased the likelihood of an elderly person being dependent for their IADL by $39 \%$, while heart disease raised that rate to $82 \%$, arthritis to $59 \%$ and lung disease to $50 \%$. For BADL and IADL dependency, the possibility of functional impairment doubled with the presence of each of these chronic diseases.

When the association between functional capacity and falls was studied, a significant association was found between the Barthel and Lawton indices and falls $\left(X^{2}=13.071 ; p=0.042 ; X^{2}=9.661 ; p=0.047\right)$, with a higher likelihood of falls in the more dependent participants. The literature regarding Portugal shows that there is insufficient attention to fall prevention, whether in private residences or during training of caretaking teams, and that this has direct consequences on the costs of hospitalization and incapacity. The current study found a significant association between IADL and impairments caused by falls $\left(X^{2}=14.261 ; p=0.027\right)$, with higher levels of dependency found among those people with sequelae such as changes in gait or mobility and resulting increases in incapacity.

It is important to point out that this study has some limitations. Most of the evaluated participants reside in the urban area of Coimbra $(n=100,86.9 \%)$ and only a minority comes from rural areas $(n=15 ; 13.1 \%)$, which may generate a possible bias in physical exercise habits. Moreover, evaluating the functional capacity of seniors in their BADL and IADL does not enable us to infer all factors that might influence functional decline. Therefore, there is a need for longitudinal studies that might record and provide increased understanding of the evolution of functional decline in seniors while identifying associated risk factors.

\section{CONCLUSION}

The results of this study enable researchers to identify the factors that may determine the functional decline of the elderly. They point to the need to adopt intervention strategies among this population that focus on preventing functional decline and maintaining seniors' functional capacities through a series of measures that can be carried out by caregivers, both formal and informal, as well as by health professionals who ought to receive specific training regarding this matter. ${ }^{36}$ Despite the fact that most elderly remain at home and are not excluded from their home communities and that they benefit from the support of their social and family networks, the high frequency of falls makes us recommend a review of the safety practices provided by both formal and informal caregivers.

The study also points to the high level of physical inactivity that influences mobility, loss of autonomy and independence and consequently an overburdening of the social network.

The study identified an association between polymedication and functional capacity, although the medication profiles were not studied. The literature regarding polymedicated elderly suggests that a therapeutic re-evaluation should be performed by specialized professionals.

\section{PROTECTION OF HUMANS AND ANIMALS}

The authors declare that the procedures were followed according to the regulations established by the Clinical 
Research and Ethics Committee and to the Helsinki Declaration of the World Medical Association.

\section{DATA CONFIDENTIALITY}

The authors declare having followed the protocols in use at their working center regarding patients' data publication.

\section{REFERENCES}

1. PORDATA: the Database of Contemporary Portugal; Resident Population. [accessed 2018 Jan 25]. Available at: https://www.ine.pt/ xportal/xmain?xpid=INE\&xpgid=ine_destaques\&DESTAQUESdest_ boui $=315156710 \&$ DESTAQUESmodo $=2$.

2. Tom SE, Adachi JD, Anderson FA, Boonen S, Chapurlat RD, Compston JE, et al. Frailty and fracture, disability, and falls: a multiple country study from the global longitudinal study of osteoporosis in women. J Am Geriatr Soc. 2013;61:327-34.

3. Resende-Oliveira C, Mota-Pinto A, Rodrigues V, Botelho A. Growing old in Portugal. In: Yushi L, editor. Global aging issues and policies. Understanding the importance of comprehending and studying the aging process. Springfield: Charles Thomas — Publishers; 2013.

4. Rebelo-Marques A, De Sousa LA, Andrade R, Ribeiro CF, Mota-Pinto A Carrilho F, et al. Aging hallmarks: the benefits of physical exercise. Front Endocrinol. 2018;9:x1-15.

5. Nogueira S, Ribeiro R, Rosado L, Franceschini S, Ribeiro A, Pereira ET. Determinant factors of functional status among the oldest old. Braz J Phys Ther. 2010;14:322-9.

6. Rosa TE, Benicio MH, Latorre MR, Ramos LR. Fatores determinantes da capacidade funcional entre idosos. Rev Saude Publica. 2003;37:40-8.

7. Rodrigues V, Mota-Pinto A, Sousa B, Botelho A, Alves C, Oliveira CR. The aging profile of the Portuguese population: a principal Ccomponent analysis. J Community Health. 2014;39:747-52.

8. Mahoney FI, Barthel DW. Functional evaluation: the Barthel Index. Md State Med J. 1965;14:61-5.

9. Lawton MP, Brody MH. Assessment of older people: self-maintaining and instrumental activities of daily living. Gerontologist. 1969;9:179-86.

10. Cronbach LJ. Coefficient alpha and the internal structure of tests. Psychometrika. 1951;16:297-334.

11. Stevens KN, Lang IA, Guralnik JM, Melzer D. Epidemiology of balance and dizziness in a national population: findings from the English Longitudinal Study of Aging. Age Aging. 2008;37:300-5.

12. Millán-Calenti JC, Tubío J, Pita-Fernández S, González Abraldes I, Lorenzo T, Fernández-Arruty $\mathrm{T}$, et al. Prevalence of functional disability in activities of daily living ( $A D L$ ), instrumental activities of daily living (IADL) and associated factors, as predictors of morbidity and mortality. Arch Gerontol Geriatr. 2010;50:306-10.

13. Freitas RS, Fernandes MH, Coqueiro RS, Reis Júnior WM, Rocha SV, Brito TA. Capacidade funcional e fatores associados em idosos: estudo populacional. Acta Paul Enferm. 2012;25:933-9.

14. Mota-Pinto A, Resende-Oliveira C. Biologia e fisiopatologia do envelhecimento. In Geriatria fundamental. Saber e praticar. Teixeira Veríssimo, editor. Lisboa: Lidel, Edições Técnicas; 2014. p.17-28.

15. Marianne J, Tilburg T, Groenewegen P, Van Groenou M. Linkages between informal and formal care-givers in home-care networks of frail older adults. Ageing Soc. 2016;36:1604-24

16. Paúl C, Fonseca AM. Envelhecer em Portugal. Psicologia, saúde e prestação de Ccuidados. Lisboa: Climepsi Editores; 2005

17. Kawabata M. The influences of diminishing family and community ties on experiences of the elderly as they face physical functional decline. The International Journal of Aging and Society. 2016;6.

18. Szczygieł N, Almeida M. Housing policies for the elderly: why should we care? Public Policy Adm. 2017;16:583-92.

19. Carvalho $B$. Os cuidados familiares prestados às pessoas idosas em situação de dependência: características do apoio informal familiar em

\section{CONFLICTS OF INTEREST}

All authors report no conflict of interest.

\section{FUNDING SOURCES}

This research received no specific grant from any funding agency in the public, commercial, or not-for-profit sectors.

Portugal. Kairós. 2010;12

20. Ciprandi D, Bertozzi F, Zago M, Ferreira CL, Boari G, Sforza C, et al. Study of the association between gait variability and physical activity. Eur Rev Aging Phys Act. 2017;14:19.

21. Frisard M, Fabre JM, Russell RD, King CM, DeLany JP, Wood RH et al. Physical activity level and physical functionality in nonagenarians compared to individuals age 60-74 years. J Gerontol A Biol Sci Med Sci. 2007;62:783-8

22. Matsudo SM, Matsudo VK, Barros TL, Araújo TL. Evolução do perfil neuromotor e capacidade funcional de mulheres fisicamente ativas de acordo com a idade cronológica. Rev Bras Med Esport. 2003;9,365-76.

23. Sasaki E, Sasaki S, Chiba D, Yamamoto Y, Nawata A, Tsuda E, et al. Age-related reduction of trunk muscle torque and prevalence of trunk sarcopenia in community-dwelling elderly: Validity of a portable trunk muscle torque measurement instrument and its application to a large sample cohort study. PLoS ONE. 2018;13: e0192687.

24. Brandão MP, Sousa L, Philp I, Cardoso MF. Portuguese older people's self-perception of their (in)dependency: a cross-sectional study. J Aging Innovation. 2015;4:3-17.

25. Marcellini F. Health perception of elderly people: the results of a longitudinal study. Arch Gerontol Geriatr Suppl. 2002;8:181-9.

26. Gallagher et al. Factors associated with self-reported health: implications for screening level community-based health and environmental studies. BMC Public Health. 2016;16:640.

27. Lee S, Staffileno BA, Fogg L. Influence of staff education on the function of hospitalized elders. Nur Outlook. 2013;61: 2-8.

28. Wong RY, Miller WC. Adverse outcomes following hospitalization in acutely ill older patients. BMC Geriatrics. 2008;8:10

29. Zelada MA, Salinas R, Baztán JJ. Reduction of functional deterioration during hospitalization in an acute geriatric unit. Arch Gerontol Geriatr. 2009;48:35-9.

30. Jyrkka J, Enlund H, Lavikainen P, Sulkava R, Hartikainen S. Association of polypharmacy with nutritional status, functional ability and cognitive capacity over a three-year period in an elderly population. Pharmacoepidemiol Drug Saf. 2011;20:514-22.

31. Crentsil V, Ricks MO, Xue QL, Fried LP. A pharmacoepidemiologic study of community-dwelling, disabled older women: Factors associated with medication use. Am J Geriatr Pharmacother. 2010;8:215-24.

32. Sinnige J, Braspenning J, Schellevis F, Stirbu-Wagner I, Westert G Korevaar J. The prevalence of disease clusters in older adults with multiple chronic diseases - a systematic literature review. PLoS ONE. 2013;8:e79641.

33. Stenholm S, Westerlund H, Head J, Hyde M, Kawachi, Pentti J, et al. Comorbidity and functional trajectories from midlife to old age: The Health and Retirement Study. J Gerontol A Biol Sci Med Sci. 2015;70:330-6.

34. Guccione AA, Felson DT, Anderson JJ, Anthony JM, Zhang Y, Wilson $\mathrm{PW}$; et al. The effects of specific medical conditions on the functional limitations of elders in the Framingham study. Am J Public Health. 1994;84,351-8.

35. Alves LC, Leiman BC, Vasconcelos ME, Carvalho MS, Vasconcelos AG Fonseca TC, et al. A influência das doenças crônicas na capacidade funcional dos idosos. Cad Saude Publica. 2007;23:1924-30.

36. Sourdet S, Lafont C, Rolland Y, Nourhashemi F, Andrieu S, Vellas B. Preventable iatrogenic disability in elderly patients during hospitalization. J Am Med Dir Assoc. 2015;16:674-81. 